\title{
Educational Banner as a Media to Oral Health during Pregnancy Phase Information for Pregnant Women with Lower Secondary Social Economy
}

\author{
Titiek Berniyanti, Hayyin Sabila Kandar, Taufan Bramantoro, Gilang Rasuna Sabdho Wening, Retno Palupi, Aryo Dwipo Kusumo \\ Department of Dental Public Health, Faculty of Dental Medicine, Universitas Airlangga, Surabaya, Indonesia
}

Abstract

Aims and Objective: Pregnant women become groups that need special attention with regard to their oral health and the health of their baby candidates. Gingivitis is very common in pregnant women due to increased estrogen and progesterone hormones. Surabaya Public Health Centre recorded incidence of periodontal disease in pregnant women between September and October 2017, that is, 42.8\%. From epidemiological research conducted, the primary data collected and problem priority listed to get the risk factor causing gingivitis with tartar caused one of them by lack of facility and infrastructure of pregnant woman to know about the importance of visit to dental health service. Subjects and Methods: This descriptive-analytical study conducted with 31 participants, with pre- and posttest design. The type of program evaluation we use in this empowerment program is the type of outcome evaluation. Evaluation of the results was conducted to measure whether pregnant mothers have already understood the material on educational banner media. Results: There is score increase between pre- and posttest. Total score on pretest of 220 is as much as $44 \%$ while the total score of posttest is 460 , that is, as much as $92 \%$. This indicates an increase in the number of questions answered correctly by $52 \%$. Conclusions: Educational banner can improve the understanding of pregnant women about the importance of visits to the dentist.

Keywords: Community empowerment, gingivitis, pregnant women

\section{INTRODUCTION}

Periodontal disease in Indonesia is the second most common disease suffered by the community $( \pm 73.50 \%)$ and as many as $4 \%-5 \%$ of residents suffer from advanced periodontal disease which can cause tooth shake and loose. ${ }^{[1]}$ According to data from the past 9 months at Surabaya Public Health Centre, $31.7 \%$ suffer from periodontal disorder. Surabaya Public Health Centre recorded the incidence of periodontal disease in pregnant women between September and October 2017 that is $42.8 \%$. Moreover, the bad Community Periodontal Index (Periodontal Severity Index) score occurred in $71 \%$ of pregnant women [Table 1].

Pregnant women become groups that require special attention with regard to their oral health and the health of their future infants. ${ }^{[2]}$ Pregnant women should be aware of the importance of maintaining oral health during pregnancy for themselves and the fetus conceived so as to avoid the occurrence of oral diseases that may affect pregnancy. In line with this, improving

\begin{tabular}{|l|l|}
\hline \multicolumn{2}{|c|}{ Access this article online } \\
\hline Quick Response Code: & Website: \\
\hline & www.jioh.org \\
\hline
\end{tabular}

oral health and health promotion can reduce the occurrence of mouth disease. ${ }^{[3]}$

Research conducted by Bamanikar and Kee in 2013 found that knowledge related to dental care is also low among pregnant women. Although majority of them (96.8\%) agree that pregnant women should check their teeth during pregnancy, only $55.9 \%$ actually practice it. Mwaiswelo and Masalu research in 2007 showed a lack of knowledge of pregnant women on dental and oral health care where only $16 \%$ of pregnant women received dental and oral health education and only $3.7 \%$ of pregnant women visited the dentist during pregnancy. Research conducted by Bianca in 405 pregnant

Address for correspondence: Dr. Titiek Berniyanti, Mayjend. Prof. Moestopo No. 47, Surabaya, East Java, Indonesia. E-mail: berniyanti@gmail.com

This is an open access journal, and articles are distributed under the terms of the Creative Commons Attribution-NonCommercial-ShareAlike 4.0 License, which allows others to remix, tweak, and build upon the work non-commercially, as long as appropriate credit is given and the new creations are licensed under the identical terms.

For reprints contact: reprints@medknow.com

How to cite this article: Berniyanti T, Kandar HS, Bramantoro T, Wening GR, Palupi R, Kusumo AD. Educational banner as a media to oral health during pregnancy phase information for pregnant women with lower secondary social economy. J Int Oral Health 2019;11:S10-2. 
women reported that half of the respondents had regular visits to the dentist before pregnancy, most visited the dentist when they had problems. ${ }^{[2]}$ Meanwhile, in the preliminary study conducted, only $9.7 \%$ of the participants who have a routine schedule of visiting dental care [Table 2].

Based on the results of epidemiological studies on the distribution of maternal gingival health status, one of the risk factors related to the health status of pregnant woman is gingivitis.

Based on the report of the number of visits of pregnant women during the last year (April 2017-April 2018) showed that of 366 pregnant women, only $8.2 \%$ who visited the dental polyclinic. In addition, from the results of epidemiological research on the relationship of Lawrence Green theory with the behavior of pregnant women visit to dentistry, it is found that knowledge is one of the things that influence the behavior of the visiting. From these data, it is concluded that the participants show a low knowledge of the importance of visiting toothpaste during pregnancy.

Limitations of human resources available in dental clinic Dupak Public Health Centre cause less optimal information transfer process while doing counseling to pregnant mothers.

Therefore, intervention is needed as a first step to overcome oral health by making an education banner to add information and improving knowledge about the importance of visiting dental and oral health services during pregnancy.

\section{Subjects and Methods}

This descriptive-analytical study conducted with 31 participants, with pre- and posttest design. The numbers of respondents gained by simple random sampling method. Methods in the implementation of this program are grouped in three stages, namely, preimplementation stage, implementation stage, and postimplementation. The next stage is the implementation

\begin{tabular}{lc}
\hline $\begin{array}{l}\text { Table 1: Participants distribution of visiting dental care } \\
\text { frequency }\end{array}$ \\
\hline Dental visit & Frequency (\%) \\
\hline Never & $13(41.9)$ \\
$1-2$ & $15 *(48.4)$ \\
Routine & $3(9.7)$ \\
Total & $31(100)$ \\
\hline *The highest visit number is $1-2$ times
\end{tabular}

Table 2: Participants distribution of Community Periodontal Index score (Periodontal Severity Index)

\begin{tabular}{lc}
\hline CPI score & Frequency (\%) \\
\hline Good (0) & $9(29)$ \\
Bad (1-2) & $22 *(71)$ \\
Total & $31(100)$ \\
\hline
\end{tabular}

*Average of the participants had bad CPI score. CPI: Community Periodontal Index of activities of empowerment of pregnant women to dental hygiene and mouth through educational banner.

All the respondents who were the subject in this study had filled the informed consent that stated their willingness for intraoral examination and filling questionnaire. Ethics approval for performing this study has been obtained from the Research Ethics Committee of Faculty of Dentistry Universitas Airlangga, with the number of ethic clearance is $78 / \mathrm{KKEPK}$. FKG/VI/2016. This research is approved by Head of Public Health Center in Surabaya, East Java Province, and running with Head of Town approval.

The empowerment program evaluated by evaluating pregnant women with checklist item and evaluation result using pre- and posttest to see understanding of empowerment participant refers to variables as follows:

1. To measure the knowledge of participants of pregnant women, as many as five participants of pregnant women given pretest.

2. Pregnant women are allowed to brush teeth immediately after nausea

3. A safe time to do dental patching and tartar cleaning is third trimester

4. Unhealthy tooth can spread the bacteria that damage the baby's teeth

5. Mothers with high levels of cavities are at risk of causing children born with cavities

6. Before pregnancy, the mother should ensure that the teeth are not hollow, healthy gums, and no tartar.

Participants are given $5 \mathrm{~min}$ to answer the questions given. Participants are instructed to provide a checklist on the correct column if the statement is considered correct and provide a checklist on the wrong column if the statement is considered wrong. After that, given a banner roll is given by putting in front of the participants of pregnant women. Then, the team gives the posttest with the same problem and time.

\section{REsuLTS}

From the results of pretest and posttest score obtained an increase in average post-test score. Before given the counseling, the total score on pretest of 220 is as much as $44 \%$. This achievement is below the mean standard score that has been made of total $50 \%$. While total score of posttest is 460 , that is as much as $92 \%$ of the question answered correctly. This indicates an increase in the number of questions answered correctly by $52 \%$.

This significant increase indicates that the educational banner program is quite effective media for dental and oral health counseling.

\section{Discussion}

Pregnant women have been accorded high priority for health education. ${ }^{[4]}$ A person's behavior may be the main cause of health problem, but it can also be the main solution. 
By changing their behavior, these individuals can solve and prevent many of their problems. ${ }^{[5]}$ Through health education, we help people to understand their behavior and how it affects their health. We encourage people to make their own choice for a healthy life. We do not force people to change..$^{[6-8]}$

Starting prevention program in population with multimedia tools more favorable because a multimedia instructional environment has an enormous potential to improve the people capability to learn ${ }^{[9]} \mathrm{A}$ learner who receives material in forms of verbal and pictorial static such as photographs or illustrations and dynamic content such as video or animation films. Their encouraging the ability to understand can be enhanced by the addition of visual forms of presentation. ${ }^{[10]}$ That is why educational banner is an effective way to deliver a health message.

It has been proved that dental health education results in positive dental habits that lead to improve oral health. ${ }^{[1]}$ With significant increase in posttest score results, the educational banner is quite effective as an educational media for pregnant women.

Another management tool that can be used to help make decisions concerning appropriate actions to fill the gaps discovered in the benchmarking process is called strengths, weaknesses, opportunities, and threats (SWOT) analysis. In this approach, the SWOTs to the program are analyzed. ${ }^{[12]}$ Besides, a creative SWOT analysis can serve as a preliminary activity to describe the current situation and to choose collectively those factors which are to be promoted. ${ }^{[13]}$ SWOT analysis of pregnant women empowerment program is as follows:

1. Strength (internal) of this empowerment program includes the material given in accordance with the evidence based, the material presented is a material that is easily understood by the general public because it is made with attractive design and interactive

2. Weakness of this program is the utilization of roll banner. The informations contained in the roll banner is limited and will be needed for more than just one roll banner

3. Opportunities (external) of this empowerment program are that there is no information available at the Public Health Centre on the importance of visiting dentists during pregnancy. The educational banner can be placed in front of the dentist room or waiting room in Public Health Centre, so that the patients can read the information there while waiting for their turn

4. Threats (external) of this empowerment program is the cost incurred for the production of high enough roll banner, so for now only, 1 roll banner is placed in the Public Health Centre area so not all pregnant women can read the banner roll if the placement is not right.

Educational banner used as an informative media to increase the visit of pregnant mother to dentist during pregnancy which is new thing for pregnant woman and has never existed in Surabaya Public Health Centre before. Dentists and midwives can add information related to the health of pregnant women with their teeth and mouth. Educational banners are laid and arranged so that every pregnant woman visiting the Public Health Centre can read them.

\section{Conclusion}

The empowerment program of pregnant women will provide information on the importance of dental visits during pregnancy and treatments that can be done according to gestational age. The results show that media educational banner can improve the understanding of pregnant women about the importance of visits to the dentist.

\section{Financial support and sponsorship}

Nil.

\section{Conflicts of interest}

There are no conflicts of interest.

\section{REFERENCES}

1. Yoto H, Anindita PS, Mintjelungan C. a PS, Mintjelungan C. Description of Gingivitis in Pregnant Mother in Tuminting Public Health Center, Manado, Indonesia. J E GiGi 2013;1.

2. Kartiningrum ED. Dental and Oral Health of Pregnant Mother in Public Health Centre Kedungsari, Mojokerto. Medica Mojopahit. Med Majapahit 2014;6.

3. Lu HX, Xu W, Wong MC, Wei TY, Feng XP. Impact of periodontal conditions on the quality of life of pregnant women: A cross-sectional study. Health Qual Life Outcomes 2015;13:67.

4. Thomas SD, Mobley SC, Hudgins JL, Sutherland DE, Inglett SB, Ange BL. Conditions and dynamics that impact maternal health literacy among high risk prenatal-interconceptional women. Int J Environ Res Public Health 2018;15. pii: E1383.

5. World Health Organization. Education for Health: A Manual on Health Education in Primary Health Care. Geneva: WHO Publication; 1988.

6. Cartland J, Ruch-Ross HS. Health behaviors of school-age children: Evidence from one large city. J Sch Health 2006;76:175-80.

7. Bovet P, Viswanathan B, Faeh D, Warren W. Comparison of smoking, drinking, and marijuana use between students present or absent on the day of a school-based survey. J Sch Health 2006;76:133-7.

8. Kelly MP, Barker M. Why is changing health-related behaviour so difficult? Public Health 2016;136:109-16.

9. Stein C, Santos NM, Hilgert JB, Hugo FN. Effectiveness of oral health education on oral hygiene and dental caries in schoolchildren: Systematic review and meta-analysis. Community Dent Oral Epidemiol 2018;46:30-7.

10. Alhayek AI, Alsulaiman MJ, Almuhanna HA, Alslem MA, Althaqib MA, Alyousef AA, et al. The effect of conventional oral health education versus animation presentation on the perception of Saudi males in primary school children. J Int Oral Health 2018;10:121-6.

11. Haque SE, Rahman M, Itsuko K, Mutahara M, Kayako S, Tsutsumi A, et al. Effect of a school-based oral health education in preventing untreated dental caries and increasing knowledge, attitude, and practices among adolescents in Bangladesh. BMC Oral Health 2016;16:44.

12. O'Donnell M. Health Promotion in the Workplace. United States of America: Delmar Thomson Learning; 2002. p. 96.

13. Hanson A. Workplace Health Promotion. United Kingdom, Bloomington:Authorhouse UK, Ltd; 2007. 